\section{A Five-year Study on the Effect of Cluster Thinning on Yield and Fruit Composition of 'Chambourcin' Grapevines}

\author{
Imed Dami, ${ }^{1}$ Dave Ferree, Anton Prajitna, and Dave Scurlock \\ Department of Horticulture and Crop Science, Ohio Agricultural Research \\ and Development Center, The Ohio State University, 1680 Madison Avenue, \\ Wooster, OH 44691
}

Additional index words. crop load, French-American hybrid, overcropping, balance, wine grape

\begin{abstract}
Chambourcin' (Vitis sp.) is a French-American hybrid cultivar that has the propensity to overcrop, and its performance under cool climate and short growing season is not known. This study was conducted for five years (2000 to 2004) to evaluate the effect of three levels of cluster thinning $(10,20$, and 30 clusters per vine) on yield and fruit composition of 'Chambourcin' grown in northeastern Ohio. Cluster thinning reduced yield per vine and crop load, but increased pruning, cluster and berry weights. Cluster thinning also improved juice composition by increasing soluble solids and pH but not acidity. It was concluded that under the climatic conditions of this study, thinning to 10 clusters per vine (or 8 clusters per meter of row) produced the lowest yield but the highest vine size with the most optimum fruit composition. Therefore, vines from the 10-cluster treatment were considered the most balanced in the 5-year study. Additionally, due to the repeated coincidence of harvest with the first fall frost, it was suggested that the site in continental Northeast Ohio is risky for commercial production and longer and warmer seasons are thus preferred.
\end{abstract}

Several French-American hybrid winegrape cultivars tend to overcrop, which can reduce growth, wine quality, and increase susceptibility to winter injury (Ferree et al., 2003; Fisher et al., 1977; Howell et al., 1987; Reynolds et al., 1986). Howell (2001) emphasized that to attain the highest sustainable yields and achieve the desired fruit maturation with varietal character, many wine grapes need some crop adjustment during the season. This is particularly important in years when weather conditions are adverse and crop level must be reduced for the vine to mature the grapes.

Crop load, which is a ratio of crop weight and pruning weight, is a practical and reliable indicator of vine balance status between shoot and fruit production(Bravdo et al., 1984, 1985; Howell, 2001; Naor et al., 2002). Kliewer and Dokoozlian(2000) define well-balanced grapevines as those that do not overcrop and ripen their fruit to desired soluble solids with a given accumulation of degree-days. They reported that optimum crop loads fall within a specific range of 4 to 10 in several vinifera cultivars. It was reported that crop load ratios were higher in hybrid cultivars, 'Seyval' (Reynolds and Wardle, 1994) and 'Chancellor' (Reynolds et al., 1995), than in $V$. vinifera. This is primarily due to the higher bud fruitfulness and larger

Received for publication 2 Dec. 2005. Accepted for publication 23 Jan. 2006. We gratefully acknowledge the partial financial support of this project provided by the Ohio Grape Industries Committee (www. ohgrapes.gov)

${ }^{1}$ To whom reprint requests should be addressed; e-maildami.1@osu.edu. clusters in most hybrids than in $V$. vinifera cultivars (Reynolds et al., 1986, 1995).

'Chambourcin' (Vitis spp) is a FrenchAmerican hybrid cultivar with fruitful latent and base buds; thus, it tends to overcrop (Ferree et al., 2003, 2004; Pool et al., 1978). It has a higher disease and winter resistance than $V$. vinifera cultivars, thus it is well adapted to Midwestern and Eastern US environmental conditions. producers and has emerged as one of the most promising red wine hybrid cultivars that produce quality wine. Furthermore, 'Chambourcin'was identified in a recent survey as the red hybrid of most interest in Ohio for producing quality wine (Ferree et al., 1997). Grape and wine producers have little experience with this cultivar due to its recent introduction to Ohio. Furthermore, growers do not commonly practice cluster thinning of this cultivar. 'Chambourcin' requires a relatively long growing season to properly mature the fruit; thus in cool seasons or years with early frosts, this characteristic may delay adequate hardening and ultimately winter survival. There are no documented reports on the best methods of cropping this cultivar when grown in cool and short growing season such as in continental Northeast Ohio. Therefore, the present study was established with the goal of identifying a suitable and sustainable crop load cific objectives were to determine the effects of different cluster thinning levels on yield and fruit composition of 'Chambourcin' grapevines; and to evaluate its overall viticultural performance in cool-climate and short season conditions of continental Northeast Ohio. Therefore, 'Chambourcin' is desired by grape of 'Chambourcin' for Northeast Ohio. The spe-
Grafted 'Chambourcin'(Seyve-Villard 12$417 \times$ Seibel 7053$)$ grapevines on rootstock 'Couderc 3309' (V. riparia $\times$ V. rupestris $)$ were planted in 1996 at a spacing of $1.25 \times 3 \mathrm{~m}$ (or 2722 vines/ha) at the Horticultural Research Unit 2, Wooster, $\mathrm{OH}$ (latitude: $40^{\circ} 47^{\prime} \mathrm{N}$, longitude: $81^{\circ} 55^{\prime} \mathrm{W}$, elevation: $311 \mathrm{~m}$ asl., Wooster silt-loam soil). Vines were trained to a unilateral cordon at a height of $1.8 \mathrm{~m}$, and were pruned to 20 nodes on 5-node spurs per vine. Beginning in 2000, all treatments were thinned to 20 shoots per vine at 24 to $30 \mathrm{~cm}$ shoot length stage. Shoot positioning and cluster thinning, but not leaf pulling, were conducted at pea-size stage to leave 10 (10CL), 20 (20CL), and 30 (30CL) clusters per vine (or 8,16 , or 24 clusters per $m$ of row) and the treatments continued on the same vines for 5 years. Each crop level treatment was established on six vines between posts and the treatments were arranged as a randomized complete block with five replications. Other standard vineyard practices including disease, insect, and weed managements were used.

The time of harvest was determined based on optimum composition of the three parameters, soluble solids (SS), $\mathrm{pH}$, and titratable acidity (TA), of grape juice. A 100-berry sample was collected at random from each treatment, weighed and crushed in a food strainer and SS, $\mathrm{pH}$, and TAdetermined on the juice using standard methodology. Furthermore, crop weight and cluster number were recorded annually for each vine. Pruning weights were also collected per vine and used to calculate crop load.

The data were analyzed using the mixed procedure of SAS (SAS Institute, Cary, N.C.). Means within each treatment were separated by Duncan's multiple range test at the $5 \%$ level. Single degree of freedom polynomial contrasts were used to test the trend response of variables to the treatments imposed.

\section{Results and Discussion}

Effect of cluster thinning on yield, pruning weight, and crop load. Crop weight was expectedly lowest for 10CL in all years; and highest for 30CL in 2002 only, but 30CL was similar to $20 \mathrm{CL}$ in 2000, 2001, 2003. In 2004, the 30CL treatment oddly had the lowest yield. This likely was due to winter injury, which affected vines with the highest crop level the most. The cumulative yield was lowest for 10CL and highest for 20CL and 30CL treatments, which were similar (Table 3). Crop weight increased linearly with increased crop level (Table 3 ). The reduction of yield following cluster thinning has been previously reported in several other grape cultivars (Howell, 2001; Kliewer and Dokoozlian, 2000; Miller and Howell, 1998; Naor et al., 2002; Reynolds et al., 1995). Furthermore, cluster and berry weights were the highest for 10CL and lowest for 30CL and followed a linear trend as well (Table 1 and 3 ). It is suggested that cluster thinning decreased crop weight per vine which resulted in an increase in cluster and berry weight. This yield compensation response is typical and has been 
Table 1. Effect of cluster thinning on yield components, pruning weight and crop load of 'Chambourcin' grapevines in 2000-04.

\begin{tabular}{|c|c|c|c|c|c|c|}
\hline $\begin{array}{l}\text { Thinning } \\
\text { treatment } \\
\text { (clusters/vine) }\end{array}$ & $\begin{array}{l}\text { Actual } \\
\text { clusters/ } \\
\text { vine }\end{array}$ & $\begin{array}{l}\text { Crop wt/ } \\
\text { vine } \\
(\mathrm{kg})\end{array}$ & $\begin{array}{c}\text { Cluster } \\
\text { wt } \\
(\mathrm{g})\end{array}$ & $\begin{array}{c}\text { 100-Berry } \\
\text { wt } \\
(\mathrm{g})\end{array}$ & $\begin{array}{c}\text { Pruning wt/ } \\
\text { vine } \\
(\mathrm{kg})\end{array}$ & $\begin{array}{l}\text { Crop } \\
\text { load }^{y}\end{array}$ \\
\hline \multicolumn{7}{|l|}{2000} \\
\hline 10 & $10 \mathrm{c}$ & $2.7 \mathrm{~b}$ & $264 \mathrm{a}$ & $227 \mathrm{a}$ & --- & --- \\
\hline 20 & $21 \mathrm{~b}$ & $4.7 \mathrm{a}$ & $229 \mathrm{ab}$ & $222 \mathrm{ab}$ & --- & --- \\
\hline 30 & $29 a$ & $4.9 \mathrm{a}$ & $178 \mathrm{~b}$ & $207 \mathrm{~b}$ & --- & --- \\
\hline \multicolumn{7}{|l|}{2001} \\
\hline 10 & $13 \mathrm{~b}$ & 3.2 & $245 \mathrm{a}$ & $224 \mathrm{a}$ & $0.49 \mathrm{a}$ & 8 \\
\hline 20 & $22 \mathrm{a}$ & 3.8 & $163 \mathrm{~b}$ & $206 \mathrm{~b}$ & $0.28 \mathrm{~b}$ & 14 \\
\hline 30 & $23 \mathrm{a}$ & 3.6 & $170 \mathrm{~b}$ & $194 \mathrm{~b}$ & $0.25 \mathrm{~b}$ & 14 \\
\hline \multicolumn{7}{|l|}{2002} \\
\hline 10 & $12 \mathrm{c}$ & $4.1 \mathrm{c}$ & $345 \mathrm{a}$ & $219 a$ & $0.32 \mathrm{a}$ & $12 \mathrm{~b}$ \\
\hline 20 & $23 \mathrm{~b}$ & $5.8 \mathrm{~b}$ & $252 \mathrm{~b}$ & $204 \mathrm{~b}$ & $0.19 b$ & $31 \mathrm{a}$ \\
\hline 30 & $31 \mathrm{a}$ & $6.7 \mathrm{a}$ & $208 \mathrm{c}$ & $210 \mathrm{ab}$ & $0.20 \mathrm{~b}$ & $34 \mathrm{a}$ \\
\hline \multicolumn{7}{|l|}{2003} \\
\hline 10 & $14 \mathrm{c}$ & $5.0 \mathrm{~b}$ & $395 \mathrm{a}$ & $247 \mathrm{ab}$ & $0.72 \mathrm{a}$ & $14 \mathrm{~b}$ \\
\hline 20 & $23 \mathrm{~b}$ & $7.6 \mathrm{a}$ & $335 \mathrm{a}$ & $255 \mathrm{a}$ & $0.33 \mathrm{~b}$ & $36 a$ \\
\hline 30 & $33 a$ & $7.6 \mathrm{a}$ & $239 \mathrm{~b}$ & $229 \mathrm{~b}$ & $0.19 \mathrm{~b}$ & $40 \mathrm{a}$ \\
\hline \multicolumn{7}{|l|}{2004} \\
\hline 10 & $12 \mathrm{~b}$ & $1.8 \mathrm{ab}$ & $154 \mathrm{a}$ & $218 \mathrm{a}$ & $0.42 \mathrm{a}$ & $5 \mathrm{~b}$ \\
\hline 20 & $19 \mathrm{a}$ & $2.3 \mathrm{a}$ & $114 \mathrm{~b}$ & $209 \mathrm{~b}$ & $0.18 \mathrm{~b}$ & $13 \mathrm{a}$ \\
\hline 30 & $18 \mathrm{a}$ & $1.7 \mathrm{~b}$ & $82 \mathrm{c}$ & $198 \mathrm{c}$ & $0.16 \mathrm{~b}$ & $12 \mathrm{a}$ \\
\hline
\end{tabular}

${ }^{z}$ Mean separation within years within columns by Duncan's multiple range test at $p \leq 0.05$.

${ }^{\mathrm{y}}$ Crop load = crop weight/pruning weight.

reported previously for other grape cultivars (Reynolds et al., 1995).

Pruning weights per vine were highest for 10CL and lowest for 20 and 30CL and decreased linearly with increasing crop levels (Table 1 and 3). Furthermore, when pruning weights were expressed in $\mathrm{kg}$ per linear meter of row, the 5 -year means were $0.31 \mathrm{~kg} \cdot \mathrm{m}^{-1}(10 \mathrm{CL})$, and $0.16 \mathrm{~kg} \cdot \mathrm{m}^{-1}$ (20CL and $\left.30 \mathrm{CL}\right)$. Based on previous recommendations by Smart and Robinson (1991), only 10CL vines had pruning weights within the optimum range of 0.3 to $0.6 \mathrm{~kg} \cdot \mathrm{m}^{-1}$. This indicates that $20 \mathrm{CL}$ and $30 \mathrm{CL}$ vines were overcropped and thus out of balance since pruning weights were not within the optimum range. Vine size (pruning weight/ vine) for those unbalanced vines had declined over the years as well (Table 1). Reports on the response of pruning weight to crop levels varied; some authors reported an increase in pruning weight as crop levels were reduced (Bravdo et al., 1985), while others reported no effect (Naor et al., 2002; Reynolds et al., 1994; Wample and Wolf, 1996).

Crop load decreased linearly with thinning and was consistently lowest for 10CL (Table 1 and 3). Crop loads between 4 and 10 were considered ideal and produced balanced vines with optimum wine quality in $V$. vinifera cultivars (Kliewer and Dokoozlian, 2000; Smart and Robinson, 1991). It was reported that grapevines with crop loads $>10$ were considered overcropped with the exception of some hybrid cultivars. In fact, Reynolds et al. (1995) reported croploads of 10 to 17 in 'Chancellor' and 18 to 28 in 'Seyval' (Reynolds and Wardle, 1994). In our study, we identified an optimum crop load derived from the 10CL treatment, because only those vines produced optimum vine size (i.e., $0.31 \mathrm{~kg} \cdot \mathrm{m}^{-1}$ of pruning weight) which did not decline over the 5-year duration of the study. In other words, the 10CL treatment yielded balanced vines. The corresponding 5 -year mean of crop load ratio was 10 (range 5 to 14). However, ratios of 23 and 25 from
20CLand 30CL, respectively, were considered high and indicated vines were overcropped and thus not balanced (Table 3 ). A recent study on 'Chambourcin' reported an optimum crop load within a similar range we found in this study (Dami et al., 2005; Kurtural, 2005).

Effect of cluster thinning on fruit composition. Soluble solids increased with cluster thinning but was not consistent over the years (Table 2). Actually, in 2003, the 30CL treatment had the highest SS; likely, related to the yield which was lowest rather than highest in 2003 as compared to previous years. The increase in SS with cluster thinning has been reported in other cultivars (Naor et al., 2002; Kliewer and Dokoozlian 2000). In general, the titratable acidity did not respond to different crop levels over the years, except in 2000 where it was highest for 10CL (Table 2). It is also worth noting that the titratable acidity was lowest in 2002; and this can be attributed to a warmer than normal season with higher heat units (Table 5). Acidity values under $10 \mathrm{~g} \cdot \mathrm{L}^{-1}$, which were attained in 2002, are most desirable by winemakers. The $\mathrm{pH}$ was consistently higher in 10CL than the other treatments (Tables 2 and 3). Overall, the fruit composition responses in 20CL and 30CL are typical of increasing crop levels, which result in a delayed fruit ripening (Naor et al., 2002).

Harvest dates in relation to growing degreedays. Besides the effect of cluster thinning, this study attempted to investigate whether 'Chambourcin' can be sustainably grown in northeastern Ohio. During this study, the mean harvest date was 9 Oct. and the frost date was 10 Oct., or $1 \mathrm{~d}$ later (Table 4 ). In addition, there are normally 160 frost-free days in Wooster (data not shown). This can be a problem for late-maturing cultivars such as 'Chambourcin' since vines would not have leaves at postharvest to harden off properly (Howell, 2001).

Table 2. Effect of cluster thinning on fruit composition of 'Chambourcin' grapevines in 2000-04

\begin{tabular}{cccc}
\hline $\begin{array}{l}\text { Thinning } \\
\text { treatment } \\
\text { (clusters/vine) }\end{array}$ & $\begin{array}{c}\text { Soluble } \\
\text { solids } \\
(\%)\end{array}$ & $\mathrm{pH}$ & $\begin{array}{c}\text { Titratable } \\
\text { acidity } \\
\left(\mathrm{g} \cdot \mathrm{L}^{-1}\right)\end{array}$ \\
\hline $\begin{array}{c}2000 \\
10\end{array}$ & $21.5 \mathrm{a}^{\mathrm{z}}$ & $3.40 \mathrm{a}$ & $11.0 \mathrm{a}$ \\
20 & $20.9 \mathrm{a}$ & $3.38 \mathrm{a}$ & $10.2 \mathrm{~b}$ \\
30 & $19.9 \mathrm{~b}$ & $3.29 \mathrm{~b}$ & $10.0 \mathrm{~b}$ \\
2001 & & & \\
10 & 21.8 & $3.23 \mathrm{a}$ & 10.9 \\
20 & 22.2 & $3.20 \mathrm{ab}$ & 10.5 \\
30 & 21.1 & $3.15 \mathrm{~b}$ & 10.7 \\
2002 & & & 8.9 \\
10 & 21.3 & $3.22 \mathrm{a}$ & 8.8 \\
20 & 19.7 & $3.14 \mathrm{~b}$ & 8.6 \\
30 & 19.8 & $3.13 \mathrm{~b}$ & 12.3 \\
2003 & & $3.16 \mathrm{a}$ & 12.1 \\
10 & $19.2 \mathrm{a}$ & $3.11 \mathrm{~b}$ & 11.9 \\
20 & $17.1 \mathrm{ab}$ & $3.08 \mathrm{~b}$ & 12.7 \\
30 & $16.6 \mathrm{~b}$ & & 12.1 \\
10 & & $3.34 \mathrm{a}$ & 12.2 \\
\hline
\end{tabular}

${ }^{2}$ Means separation within years within columns by Duncan's multiple range test at $p \leq 0.05$. 
Table 3. Trends of the 5-year means of yield, growth, fruit composition, and cumulative yield and pruning weight of 'Chambourcin' in response to cluster thinning.

\begin{tabular}{|c|c|c|c|c|c|c|c|c|c|c|c|}
\hline $\begin{array}{l}\text { Thinning } \\
\text { treatment } \\
\text { (clusters/vine) }\end{array}$ & $\begin{array}{l}\text { Actual } \\
\text { clusters/ } \\
\text { vine }\end{array}$ & $\begin{array}{l}\text { Crop wt/ } \\
\text { vine } \\
(\mathrm{kg})\end{array}$ & $\begin{array}{l}\text { Cumulative } \\
\text { crop wt/vine } \\
(2000-04) \\
(\mathrm{kg})\end{array}$ & $\begin{array}{c}\text { Cluster } \\
\text { wt } \\
\text { (g) }\end{array}$ & $\begin{array}{c}\text { 100-Berry } \\
\text { wt } \\
(\mathrm{g})\end{array}$ & $\begin{array}{c}\text { Pruning } \\
\text { wt/ } \\
\text { vine } \\
(\mathrm{kg})\end{array}$ & $\begin{array}{c}\text { Cumulative } \\
\text { pruning wt/vine } \\
(2001-04) \\
(\mathrm{kg})\end{array}$ & $\begin{array}{l}\text { Crop } \\
\text { load }\end{array}$ & $\begin{array}{l}\text { Soluble } \\
\text { solids } \\
(\%)\end{array}$ & $\mathrm{pH}$ & $\begin{array}{c}\text { TA } \\
\left(\mathrm{g} \cdot \mathrm{L}^{-1}\right)\end{array}$ \\
\hline 10 & 12 & 3.4 & 15.5 & 250 & 227 & 0.39 & 1.60 & 10 & 21.3 & 3.27 & 11.2 \\
\hline 20 & 22 & 4.9 & 21.3 & 219 & 219 & 0.21 & 0.90 & 23 & 20.5 & 3.23 & 10.7 \\
\hline 30 & 27 & 4.9 & 21.2 & 175 & 208 & 0.20 & 0.78 & 25 & 20.1 & 3.20 & 10.7 \\
\hline Linear & $* * *$ & $* *$ & $* *$ & $* *$ & $*$ & $* * *$ & $* * *$ & $* *$ & $*$ & $*$ & NS \\
\hline Quadratic & NS & NS & NS & NS & NS & NS & NS & NS & NS & NS & NS \\
\hline
\end{tabular}

NS,*,**,****Nonsignificant, significant at $p \leq 0.05,001$, or 0.001 , respectively; $\mathrm{L}=$ linear, $\mathrm{Q}=$ quadratic

Table 4. Dates of harvest relative to cumulative growing degree-days and coldest temperatures in 20002004 at the 'Chambourcin' vineyard location in Wooster, Ohio.

\begin{tabular}{lccc}
\hline Year & Harvest date & GDD harvest ${ }^{2}$ & Coldest temp $\left({ }^{\circ} \mathrm{C}\right) /$ date \\
\hline 2000 & 18 Oct. & 1,479 & $-21.5 / 25 \mathrm{Jan}$. \\
2001 & 10 Oct. & 1,553 & $-15.6 / 9 \mathrm{Jan}$. \\
2002 & 1 Oct. & 1,692 & $-15.5 / 4 \mathrm{Dec}$. \\
2003 & 6 Oct. & 1,466 & $-24.3 / 27 \mathrm{Jan}$. \\
2004 & 12 Oct. & 1,515 & $-22.3 / 25 \mathrm{Jan}$. \\
Mean & 9 Oct. & 1,541 & -19.8 \\
\hline
\end{tabular}

${ }^{2}$ Growing degree-days accumulation (base $10{ }^{\circ} \mathrm{C}$ ) from 1 Apr. through harvest date calculated as follows: daily (maximum temperature + minimum temperature/2) - 10. Data from OARDC weather station.

This would hinder proper cold acclimation and render those vines more vulnerable to winter injury (Table 4). Over the 5-year study, the coldest temperatures were experienced in 2003 and 2004 and caused bud injury but no trunk injury except for 30CL vines (data not shown). Yields were most affected in 2004 even though 2003 was colder (Tables 1 and 4). It is suggested that in 2003, acclimation conditions were more favorable for higher bud cold hardiness than that in 2004; at which temperatures fluctuated and reached $15^{\circ} \mathrm{C}$ few days prior to the freeze event (data not shown). Thus, vines likely deacclimated and were less hardy in January 2004 than in 2003.

The mean annual growing degree-days (GDD base $10^{\circ} \mathrm{C}$ ) through harvest were 1,541; and it was shown that the year 2002 with 1,692 GDD produced the best vintage in the 5 -year study (Steiner et al., 2003). The other vintages, however, produced acceptable fruit and wine quality but with suboptimum SS, TA(Table 1), phenolics, and anthocyanins (data not shown). Based on this study and other reports (Dami et al., 2005; Kurtural, 2005), it is suggested that Chambourcin would produce the highest fruit and wine quality under a longer growing season with heat accumulation of $>1,667$ GDD.

In conclusion, 'Chambourcin' grapevines require cluster thinning to $10 \mathrm{CL}$ per vine or eight clusters per $m$ of row, which produced the most balanced vines with optimum crop load and fruit composition. However, the lack of enough degree-days combined with a short growing season may preclude this cultivar from producing sustainably in this region. It is, therefore, recommended that 'Chambourcin' is most suitable in regions with longer growing season ( $\geq 170$ frost-free days) and higher degree-days ( $\geq 1,667$ GDD) in Ohio and other midwestern and eastern states.

\section{Literature Cited}

Bravdo, B., Y. Hepner, C. Loinger, S. Cohen, and H. Tabacman. 1984. Effect of crop level on growth, yield and wine quality of a high yielding Carignane vineyard. Amer. J. Enol. Viticult. 35:247-252.

Bravdo, B., Y. Hepner, C. Loinger, S. Cohen, and H. Tabacman. 1985. Effect of crop level and crop load on growth, yield, must and wine composition and quality of Cabernet Sauvignon. Amer. J. Enol. Viticult. 36:125-131.

Dami, I. E., D.C. Ferree, S.K. Kurtural, and B.H. Taylor. 2005. Influence of cropload on 'Chambourcin' yield, fruit quality, and winter hardiness under midwestern United States environmental conditions. Acta Hort. 689:203-208.

Ferree, D.C., G.A.Cahoon, D.M. Scurlock, and M.V. Brown. 2003. Effect of time of cluster thinning grapevines. Small Fruit Rev. 2:3-14.

Ferree, D.C., R. Riesen, and J. Gallander. 1997. Cultivars desired by Ohio wineries. Proc. Ohio Grape-Wine Short Course. pp. 118-122.

Ferree, D.C., D.M. Scurlock, T. Steiner, and J. Gallander. 2004. 'Chambourcin' grapevine response to crop level and canopy shade at bloom. J.Amer. Pomol. Soc. 58:135-141.

Fisher, K.H, D.A. Butt, J. Wiesa, and V.A. Dirks. 1977. Cluster thinning 'DeChaunac' French hybrid grapes improve vine vigor and fruit quality in Ontario. J. Amer. Soc. Hort. Sci. 102:162-165.

Howell, G.S. 2001. Sustainable grape productivity and the growth-yield relationship: A review. Amer. J. Enol. Viticult. 52:165-174.
Howell, G.S., T.K. Mansfield and J.A. Wolpert. 1987. Influence of training system, pruning severity, and thinning on yield, vine size and fruit quality of 'Vidal blanc' grapevines. Amer. J. Enol. Viticult. 38:105-112.

Kliewer, W.M. and N.K. Dokoozlian. 2000. Leaf area/crop weight ratios of grapevines: Influence on fruit composition and wine quality, $\mathrm{p}$. 285-295. Proc. ASEV 50th Anniversary Annu. Mtg., Seattle, Wash., 19-23 June.

Kurtural, S.K. 2005. Balanced cropping of 'Chambourcin' grapevines and a special decision support system for vineyard site selection in southern Illinois, p. 131. PhD diss. S. Ill. Univ., Carbondale.

Miller, D.P. and G.S Howell. 1998. Influence of vine capacity and crop load on canopy development, morphology, and dry matter partitioning in Concord grapevines. Amer. J. Enol. Viticult. 49:183-190.

Naor, A., Y. Gal, and B. Bravdo. 2002. Shoot and cluster thinning influence vegetative growth, fruit yield, and wine quality of 'Sauvignon blanc' grapevines. J. Amer. Soc. Hort. Sci. 127:628-634.

Pool, R.M., C. Pratt, and H.D. Hubbard. 1978. Structure of base buds in relation to yield of grapes. Amer. J. Enol. Viticult. 29:36-41.

Reynolds, A.G., R.M. Pool, and L.R. Mattick. 1986. Effect of shoot density and crop control on growth, yield, fruit composition and wine quality of 'Seyval blanc' grapes. J. Amer. Soc. Hort. Sci. 111:55-63.

Reynolds, G.A. and D.A. Wardle. 1994. Impact of training system and vine spacing on vine performance and berry composition of Seyval blanc. Amer. J. Enol. Viticult. 45:444-451.

Reynolds, G.A., D.A. Wardle, and A.P. Naylor. 1995. Impact of training system and vine spacing on vine performance and berry composition of Chancellor. Amer. J. Enol. Viticult. 46:88-97.

Smart R., and M. Robinson. 1991. Sunlight into wine: a handbook for winegrape canopy management. 1 st ed. Winetitles, Adelaide, Australia.

Steiner, T., J. Gallander, D. Ferree, and D. Scurlock. 2003. Influence of crop level on 'Chambourcin' wine quality,p. 121-123.Proc. Ohio Grape-Wine Short Course.

Wample, R.L. and T.K. Wolf. 1996. Practical considerations that impact vine cold hardiness. In Proc. 4th Intl. Symp. Cool Climate Enology and Viticulture. T. Henick-Kling et al. (eds.). p. 22-38. N.Y. State Agr. Expt. Stat., Geneva, N.Y. 